\section{UNUSUAL NESTING SITE OF COPPERSMITH BARBET MEGALAIMA HAEMACEPHALA (MÜLLER) IN RESIDENTIAL AREA OF LUDHIANA CITY}

\section{Tejdeep Kaur Kler}

Assistant Ornithologist, Department of Zoology and Fisheries, Punjab Agricultural University, Ludhiana, Punjab

web supplement

On 15 August 2003 I sighted from the I floor of my house, a bird slightly dumpier than a house sparrow perching on an electric wire over a busy street at $1800 \mathrm{hr}$ in the Model Town area of Ludhiana city. After a minute or two, it flew to perch on cable TV wires supported by bamboo poles about 14-15ft in height on the other side of the lane. The bird was only 10ft away from my position. The characters like crimson breast and forehead, yellow throat and green streaked under parts were very distinctive of Crimson-breasted Barbet or Coppersmith Barbet Megalaima haemacephala (Müller). During the observation period of 10min, the bird perched on three different sites on cable TV wires, before flying away.

Similarly on 16 August, I noticed the bird at around $1805 \mathrm{hr}$ perching on a point near the same bamboo poles. It made very deep, quite low monotonous calls, which were repeated after every 6 to $8 \mathrm{sec}$. After $10 \mathrm{~min}$, the bird perched on the tip of the bamboo pole and soon after entered into the hollow of the bamboo pole, raising its head out after $2 \mathrm{~min}$. It looked around moving its head for $2 \mathrm{~min}$ and then lowered it into the pole, it did not come out for the next $10 \mathrm{~min}$.

I observed the Barbet residing in the bamboo pole (Image $1^{\mathrm{w}}$ ) regularly from 16 August to 20 November both in the mornings and evenings either from the I floor or standing in the verandah of the house. There was variation in the nest leaving time in the mornings and nest returning time in the evenings with change in day length.

The barbet was observed changing its nest leaving time from $0600 \mathrm{hr}$ to $0630 \mathrm{hr}$ during this period and the time shift in the nest returning time was from $1820 \mathrm{hr}$ to $1730 \mathrm{hr}$. Although there are two municipal parks about 150 feet away from the bamboo pole nesting site, it was surprising to note that the bird continued to occupy its rather unusual nest undeterred by the regular fireworks display by the children on the street in the evenings from Dusshera festival (2 October) up to Diwali (25 October).

According to Ali (1996), "The Crimson-breasted Barbet built its nest in hole excavated in a snag of a dead softwood branch such as of the Coral or Drumstick trees, at moderate heights; when in a horizontal branch, the entrance hole is on underside".

(C) Zoo Outreach Organisation; www.zoosprint.org Manuscript 1122; Received 03 December 2003; Revised received 04 April 2005; Finally accepted 31 May 2005; Date of publication 21 August 2005
Jose and Zacharias (2003) mentioned Coppersmith Barbets inhabiting four different habitat types namely urban, scrub jungle, woodland and secondary jungle in the Calicut University Campus, Kerala. The observations taken on the breeding of the Northern Green Barbet M. zeylanica at the Punjab Agricultural University at Ludhiana revealed that it nested in the Dek tree Melia azaderach hole and raised its first and second brood in the months of April and June (Kler, 2003). Coppersmith Barbet have been found common in occurrence and as resident breeders in all types of forest patches within the Kawal Wildlife Sanctuary, Andhra Pradesh (Srinivasulu, 2004). Jayson and Mathew (2002) had cited White-cheeked Barbet $M$. viridis among the seven species recorded throughout the year at the Mukkali in the Western Ghats of southern India. These studies did not point to any unusual nesting behaviour of either Coppersmith or any other barbet species. Hence this observation was considered worthy of reporting.

\section{REFERENCES}

Ali, S. (1996). The Book of Indian Birds. $12^{\text {th }}$ Edition. Bombay Natural History Society, Bombay.

Jayson, E.A. and D.N. Mathew (2002). Structure and composition of two birds communities in the southern Western Ghats. Journal of the Bombay Natural History Society 99(1): 8-25.

Jose, B. and V.J. Zacharias (2003). Distribution of birds in relation to vegetation in the Calicut University Campus, Kerala. Zoos' Print Journal 18(9): 1187-1192.

Kler, T.K. (2003). Some aspects in the breeding biology of the Northern Green Barbet Megalaima zeylanica caniceps (Franklin). Pestology 27(10): 32- 34 .

Srinivasulu, C. (2004). Birds of Kawal Wildlife Sanctuary, Andhra Pradesh, India. Journal of the Bombay Natural History Society 101(1): $3-25$.

${ }^{w}$ see Image 1 in the web supplement at www.zoosprint.org

\section{Book \\ Status of South Asian Non-volant Small Mammals}

This 600-page book is the most up-to-date compilation of information on 185 species of Nonvolant Small Mammals occurring in South Asia. With more than 20 experts contributing information, the book brings out the report of the Conservation Assessment and Management Plan (CAMP) Workshop status assessments of the species in the wild at the global as well as at the national/regional levels using the latest IUCN Red List Categories and Criteria. The compilation includes exhaustive literature search, personal observations, most recent field information, distirbution maps as well as detailed locality information for every species.

The book will be released by 1 September 2005 and those of you interested in ordering a copy of the book may contact the publishers, Zoo Outreach Organisation at <zooreach@vsnl.com> for more information and price. 